\title{
Giant Cells Tumors of Synovial Sheaths of the Hand are Benign Tumors with a Good Prognosis
}

Cesar Edgar ${ }^{1 *}$, Trey Rafael ${ }^{1}$, Robert Mason ${ }^{1}$ and Diego Luis ${ }^{1}$

${ }^{1}$ Department of Dermatology, WA, USA.

*Corresponding Author : Cesar Edgar, Department of Dermatology, WA, USA, Email: cedgar@gmail.com

Received date: October 04, 2017;Accepted date : November 01, 2017; Published date: November $01,2017$.

Citation : Cesar Edgar, Trey Rafael, Robert Mason and Diego Luis,Giant Cells Tumors of Synovial Sheaths of the Hand are Benign Tumors with a Good Prognosis. J .Dermatology and Dermatitis. Doi: http://dx.doi.org/ 10.31579/ 2578-8949.2017/019.

Copyright : (c) 2017 Cesar Edgar. This is an open-access article distributed under the terms of The Creative Commons Attribution License, which permits unrestricted use, distribution, and reproduction in any medium, provided the original author and source are credited.

\begin{abstract}
Introduction: The giant cells tumors (GCT) of the hand are common benign tumors that pose a recurrence problem. The aim of our study is to analyze epidemiological and clinical data, evaluate results and determine the recurrence risk factors.

Materials and Methods: This is a retrospective study of 50 patients operated between 2003 and 2015 for a (GCT) of the hand, we observed epidemiological data, clinical outcome (quotation TAM score Kapandji and quick DASH), the appearance of recurrence, the histological appearance, localization, excision margins and invasion of adjacent anatomical structures were analyzed.

Results: We report a retrospective study over thirteen years of 50 cases of GCT of the hand, with a mean age of 42 years and a sex ratio of $1 / 3$. The motive for consulting was the presence of a digital mass, followed by discomfort bending in $20 \%$. Palmar localization was found in 54\%, especially at the second ray (30\%) and facing the distal phalanx (38\%). The radiograph showed soft tissue opacity in $60 \%$ of cases. All patients underwent surgery, the macroscopic appearance showed an encapsulated, lobed and yellow chamois tumor in $80 \%$ of cases. The mean follow up was 30 months with extremes of 2 months to 10 years. We noted 5 recurrences one of which recurred twice; the average time to recurrence was 22 months and ranged from 6 months to 36 years. In each subsequent offense we noted an intra-articular tumor development in 4 cases and tendon erosion in one case. Functional complications type of stiffness in flexion in 2 cases and hypoesthesia of a finger in 2 cases. The quick way DASH was 2.2 on 100.

Conclusion: The GCT of synovial sheaths of the hand are a benign tumors with a good prognosis, the main problem is the risk of recurrence that depends on the type of tumor, intra articular tumor development and quality of tumor resection.
\end{abstract}

Keywords: giant cells tumors; tendon sheath; recurrence; hand tumors; hand surgery.

\section{Introduction}

Giant cell tumor of the tendon sheath represents the localized form of pigmented villonodular synovitis. They are found mostly at the hands ( $80 \%$ of cases) where it is the second soft tissue tumor after arthrosynovial cyst [1]. The diagnosis is clinical, the confirmation is histological. The Treatment is exclusively surgical; it is sometimes difficult due to local extension and invasion of digital noble structures. Recurrences are frequent and pose a management problem of these tumors. The aim of our study is to analyze epidemiological and clinical data, evaluate results and determine the recurrence risk factors.

\section{Material and Methods}

This is a retrospective study of 50 patients operated on between 2003 and 2015 for a (GCT) of the hand, were observed epidemiological data, clinical outcome (quotation TAM score Kapandji and quick DASH), appearance recurrence, the histological appearance, localization, surgical margins and invasion of adjacent anatomical structures were analyzed.

\section{Results}

Our series is made of 50 patients, predominantly female (38 women and 12 men), mean age was 42 years, ranging from 16 to 75 years, the predominant age range was 40 to 50 years with 20 cases. The dominant side is affected in $60 \%$ of cases. The tumor location was: thumb: 10 cases, the index: 15 cases, middle finger: 12 cases, the ring finger: 8 cases, the little finger: 4 cases and a distal palmar location at hand, it was in all cases an isolated location.
The swelling was palmar in 26 cases, back in 15 cases, latero-digital in 9 cases. The distal interphalangeal localization was the most frequent: $32 \%$. Consultation time was after 3 years on average, ranging from 2 months to 9 years.

The functional signs are dominated by the tumefaction with a slow evolution, spontaneous appearance, painful in 30\% of cases. Digital mobility is decreased in (20\% of cases). We noted paresthesias in 2 cases. The clinical examination revealed a tumor of firm consistency, multilobed, deeply adhering in $30 \%$ of cases, painless in $70 \%$ of cases and without inflammatory signs. Radiography was associated in 7 cases ultrasound showed soft tissue opacity in $60 \%$ of cases, a bone print or juxta articular geode and normal in $20 \%$ of cases. No MRI was performed. The clinical suspicion was $50 \%$. The average tumor size was $14 \mathrm{~mm}$ with a range of 5 to $30 \mathrm{~mm}$. The macroscopic aspect showed a pseudoencapsulated lesion coloring: buff yellow (80\%), lobed, nodular. The presumed diagnosis: $85 \%$.

The mean follow up was 30 months and ranged from 2 months to 10 years. We noted 5 recurrences one of which recurred twice. The average time to recurrence was 22 months and ranged from 6 months to 36 years. In each subsequent offense we noted an intraarticular tumor development in 4 cases and tendon erosion in one case. Functional complications type of slight stiffness in bending in 2 cases and hypoesthesia of a finger in 2 cases. The quick way DASH was 2.2 on 100. 


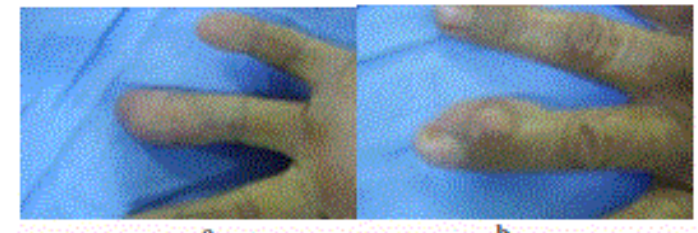

b

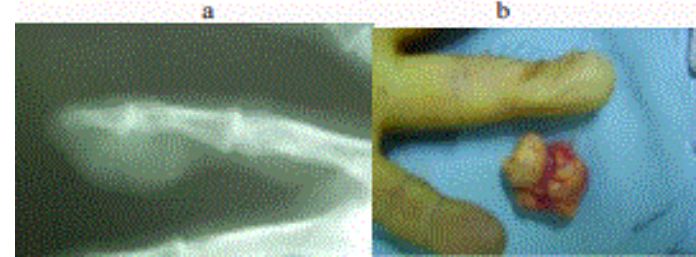

Figure $1(\mathrm{a} \& \mathrm{~b})$ TCG of the left ring finger developed around the IPD, c) radiological aspect that shows soft tissue swelling, d) intraoperative view after removal of the tumor.

\section{Discussion}

GCTs are part of benign soft tissue tumors of the hand, this is the second soft tissue tumor after synovial cysts [1]. In Posh [2] study, it represents $10 \%$ of tumors of the hand where it is $13 \%$ according to Boyes [3], $4.75 \%$ according to Glicenstein et al. [4], $8.9 \%$ according to Leclercq [5] and $10.8 \%$ according to Marty et al. [6]. It is a tumor that predominantly affects women and occurs between 20 and 60 years [7]. In accordance with the literature we found a female predominance in our series with a mean age of 42 years (Figure 1). GCTs are usually unique and located in more than $80 \%$ in the fingers [8]. The index is most often affected followed by little finger; the thumb is the less affected [9]. The tumor develops most often next to the DIP joint or MCP (Table 1). The main problem is the risk of recurrence that depends on the type of tumor (Figure 2), intra articular tumor development and quality of the tumor resection. More rarely it is found near a PIP joint [10]. In our series we found two palmar locations, for the finger locations the ring finger is the most affected. Unusual locations has been reported such a location in the palm of the hand [11]. Subungual localization [12,13] and a double localization on the thumb without contact between the two tumors [14,15]. GCT is as a generally single mass (), painless, slowgrowing that can be spread over twenty years (from a few months to 30 years), variable in size from $0.5 \mathrm{~cm}$ to $5 \mathrm{~cm}$, lobed, adherent to the deep structures and mobile compared to superficial level except for distal tumors where it may exist a skin adhesion. The pain was present in $30 \%$, with a period of evolution of 20 months ( 3 months to 5 years) on average. They measured $2 \mathrm{~cm}$ of wide axis on average $(1 \mathrm{~cm}$ to 5 $\mathrm{cm}$ ) and they were all movable relative to the superficial and adherent to the deep plan. Standard radiographs allow especially seeing opacity of the soft tissues, cortical erosion, IPD osteoarthritis and periosteal reaction. Intra tumor calcifications and osteolysis are exceptional [16]. Park [14] noted 15 bone lesions in 155 cases and De Schepper et al. [17] reported 4 cases of periosteal erosions and 2 cases of osteolysis. All authors agreed that the existence of bone lesions is correlated with a high rate of recurrence. In our series, all patients had hand radiographs. This has only objectified opacity soft tissue in 30 patients and lack of calcification and bone lesions. Ultrasound confirms the tissular structure of the mass without prejudging its etiology. The GCT is presented in ultrasound as a homogeneous mass, hypo echoic, adjacent to tendons with detection of blood flow to the arterial Doppler (Figure 3). Ultrasonography was performed in ten of our patients, it showed a hypo echoic mass poorly vascularized [18]. MRI has a very interesting contribution to the GCT; it allows establishing a precise lesional assessment of the lesions and local exploration [17]. At MRI, the tumor has welldefined limits in contact with a synovial sheath. We practiced this examination to our patients. The treatment of GCT is the complete surgical excision, which is the only guarantee to prevent recurrence $[19,20]$. The difficulties in achieving this excision are related to tumor volume, itself related to the consultation delay due to the fact that these tumors are painless and minimally intrusive functionally [21].
The incision is oriented by clinical examination and para-clinical and is adapted to each location. The goal is to allow exposure of the entire tumor and individualization of different noble elements of the finger. The change is mainly dominated by relapses that vary depending on the series from $0 \%$ to 26\%. Al-Qattan [22] reported 5 recurrences over a series of 43 cases, these tumors are unencapsulated, several factors were implicated in the recurrence of GCT other than the quality of surgical resection, bone and joint damage, cellularity and mitotic activity of the tumor, the tumor: NM23 H1 and negative tumor type II $[23,24]$. Radiation therapy appears to reduce the risk of recurrence, which decrease from $20 \%$ to $4 \%$ according to Kotwall et al. [25]. In our series, all our patients had a surgical resection without adjuvant radiotherapy, we noted two recurrences. Histological examination is the only certainty exam.

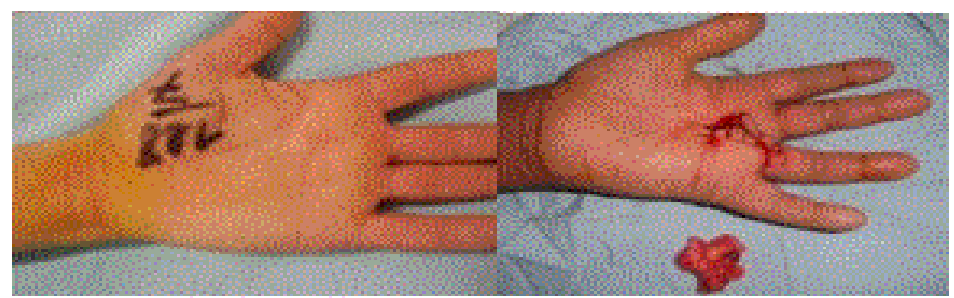

Figure 2 Rare Location of TCG at the palm of the hand: clinical and intraoperative aspect.
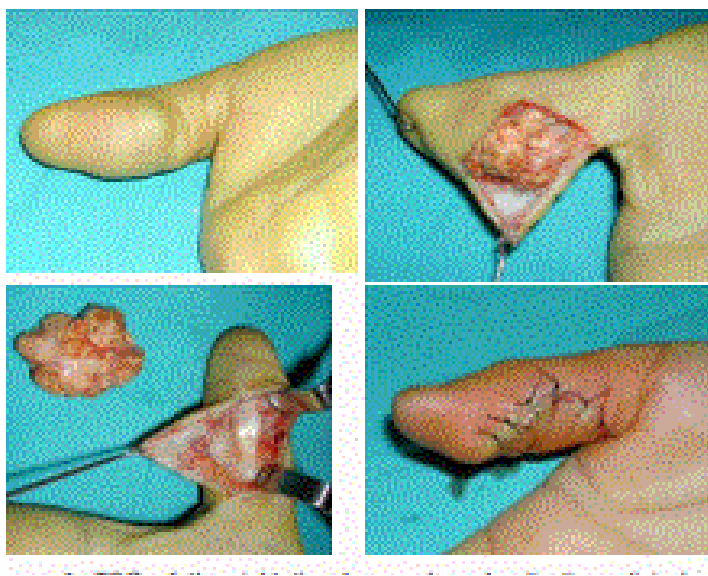

Figure 3 TCG of the right thumb, a palmar localization: clinical and intraoperative aspect

\section{Conclusion}

The GCT of synovial sheaths of the hand are benign tumors with a good prognosis, in fact, a clinical diagnostic presumption and simple radiological assessment, followed by surgical excision biopsy with histological confirmation, is the best approach for the management of these tumors. The main problem is the risk of recurrence that depends on the type of tumor, intra articular tumor development and quality of tumor resection.

\section{References}

1. Messoudi A, Fnini S, Labsaili N, Ghrib S, Rafai M, Largab A. [Giant cell tumors of the synovial sheaths of the hand: about 32 cases]. Chir Main. 2007;6(3):165-9.

2. Posch JL. Tumors of the hand. J Bone Joint Surg Am. 1956;38A(3):517-39.

3. Boyes JH. Bunnell's surgery of the hand. 5th edition. Philadelphia: Lippincott; 1970.

4. Glicenstein J, Ohana J, Leclerq C. Tumours of the hand. Berlin: Spriger Verlag; 1988.

5. Leclerq C. Hand tumors. In: Egloff D, editor. Tumors of the hand. London: Taylor and Francis; 2004.

6. Marty FL, Marteau E, Rosset P, Faizon G, Laulon J. [A retrospective study of a series of 623 hand and wrist tumors in adults]. Chir Main. 2012;29(3):183-7. doi.org/10.1016/j.main.2010.03.008 
7. Sherry JB, Anderson W. The natural history of pigmented villonodular synovitis of tendon sheaths. J Bone Joint Surg Am. 1955;37-A(5):1005-11.

8. Monoghan H, Salter DM, Al Nafussi A. Giant cell tumor of tendon sheath: clinical pathological features of 71 cases. J Clin Pathol. 2001;54(5):404-7.

9. Leneveu E, Prévot J, Dautel G, Lascombes P. [Villonodular synovitis of the wrist. Apropos of a case in an adolescent]. Ann Chir Main Memb Super. 1994;13(4):274-7. doi.org/10.1016/S0753-9053(05)80007-9

10. Fyfe IS, MacFarlane AU. Pigmented villonodular synovitis of the hand. Hand. 1980;12(2):179-88.

11. Mizushima J, Nogita T, Ooe M, Kawashima M. A case of giant cell tumor of the tendon sheath developing on the palm. J Dermatol. 1994;21(10):776- 8.

12. Abimelec P, Cambiaghi S, Thioly D, Moulonguet I, Dumontier C. Subungual giant cell tumor of the tendon sheath. Cutis. 1996;58(4):273-5

13. Richert B, Andr J. Laterosubungual giant cell tumor of the tendon sheath: an unusual location. J Am Acad Dermatol. 1999;41(2):347-8. doi.org/10.1016/S0190-9622(99)70384-1

14. Park JW. Multiple separated giant cell tumors of the tendon sheath in a thumb. J Am Acad Dermatol. 2006;54(3):540-2. doi.org/10.1016/j.jaad.2005.06.024

15. Fnini S, Ouarab M, Cohen D, Trafeh M. [Giant cell tenosynovial tumor, spread in the forearm soft tissues. A case report]. Chir Main. 2001;20(3):236-40. doi.org/10.1016/S12973203(01)00040-3

16. Karasick D, Karasick S. Giant cell tumor of tendon sheath: spectrum of radiologic findings. Skeletal Radiol. 1992;21(4):21924. doi.org/10.1007/BF00243061

17. De Schepper AM, Hogendoorn PC, Bloem JL. Giant cell tumors of the tendon sheath may present radiologically as intrinsic osseous lesions. Eur Radiol. 2007;17(2):499-502. doi.org/10.1007/s00330-006-0320-4
18. Middleton WD, Patel V, Teefey SA, Boyer MI. Giant cell tumors of the tendon sheath: analysis of sonographic findings. AJR Am J Roentgenol. 2004;183(2):337-9. 10.2214/ajr.183.2.1830337

19. van der Heijden L, Gibbons CL, Hassan AB, Kroep JR, Gelderblom $\mathrm{H}$, van Rijswijk CS, et al. A multidisciplinary approach to giant cell tumors of tendon sheath and synovium--a critical appraisal of literature and treatment proposal. J Surg Oncol. 2013;107(4):433-45.

20. Lanzinger WD, Bindra R. Giant cell tumor of the tendon sheath. J Hand Surg Am. 2013;38(1):154-7.

21. Lancigu R, Rabarin F, Jeudy J, Saint Cast Y, Cesari B, Fouque PA, et al. Giant cell tumors of the tendon sheaths in the hand: review of 96 patients with an average follow-up of 12 years. Orthop Traumatol Surg Res. 2013;99(4):S251-4. doi.org/10.1016/j.otsr.2013.03.008

22. Al-Qattan MM. Giant cell tumours of tendon sheath: classification and recurrence rate. J Hand Surg Br. 2001;26(1):72-5. doi.org/10.1054\%2Fjhsb.2000.0522

23. Jalgaonkar A, Dhinsa B, Cottam H, Mani G. Giant cell tumours of tendon sheath of the hand: causes and strategies to prevent recurrence. Hand Surg. 2011;16(2):149-54. doi.org/10.1142/S0218810411005242

24. Williams J, Hodari A, Janevski P, Siddiqui A. Recurrence of giant cell tumors in the hand: a prospective study. J Hand Surg. 2010;35(3):451-6. doi.org/10.1016/j.jhsa.2009.12.004

25. Kotwall PP, Gupta V, Malhotra R. Giant cell tumor of tendon sheath: is radiotherapy indicated to prevent recurrence after surgery. $\mathrm{J}$ Bone Joint Surg Br. 2000;82(4):571-3. https://doi.org/10.1302/0301620X.82B4.0820571 